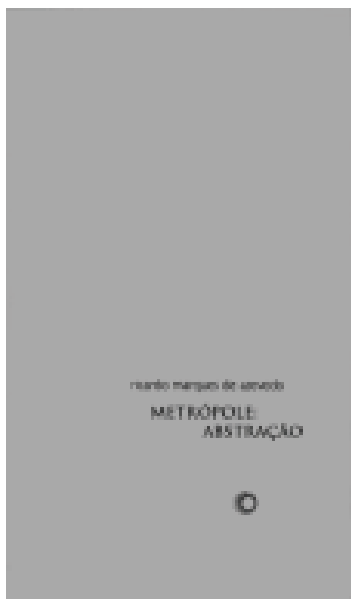

\title{
Metrópole: abstraÇão
}

\author{
AZEVedo, Ricardo Marques de. São Paulo: \\ Perspectiva, 2006, i44P. (Coleção Estudos, N. 224).
}

\section{Andréa Buchidid Loewen}

\section{SKIAgRAPHiA DA METRÓPOLE}

A Editora Perspectiva lançou, em sua coleção Estudos, o livro Metrópole: Abstração, de Ricardo Marques de Azevedo. A obra é fruto de investigação, iniciada em 1984 no programa de pós-graduação em Filosofia da Faculdade de Filosofia, Letras e Ciências Humanas da Universidade de São Paulo, que resultou na tese de doutorado defendida em 1993 e agora, longa e diligentemente revista, vem à luz, descerrando um vigor e uma atualidade a qual em muito a distancia dos escritos estritamente historiográficos.

Partindo da consolidação das capitais européias no século 18 - Paris, Madri, Turim, Londres -, velhas cidades cujas reordenações se espelham na renovada cena da Roma Triumphans, o autor explicita como a incumbência da representação do poder que se Ihes atribui impõe não apenas a conformação de novos lineamentos sobre vetustos tecidos, mas também a coreografia de rotinas, normas e usos para a população heterogênea que nelas se aglomera. Na ordenação reticulada e nos núcleos irradiantes entrelaçados às velhas tramas, entremetem-se entre a corte e suas tropas de serviçais, acólitos e burocratas, levas de camponeses também assimilados pelo comércio ou pelos ofícios encarregados do provimento de demandas das utilidades, ou das futilidades, recém-criadas.

Nos dois primeiros capítulos, manifestando a distinção qualitativa entre capitais e cidades de província, Ricardo Marques deslinda a formação das metrópoles - hipertrofiados centros de uma vida pública comparável apenas à da Roma pagã - e delineia o ambiente de encontro entre estranhos, no qual cada um pode, dissimuladamente, representar personagens e apresentar atitude impessoal, apática. Tal representação pressupõe e estimula a criação de códigos capazes de evidenciar as condições sociais reivindicadas pelas personagens, assim, as metrópoles assistem à instalação das modas, ordem de convenção cuja atualização é passível de ser aferida. Desse modo, recorda o autor, "o démodé nunca é o antigo, mas aquilo que acabou de passar e, segundo as coerções do 
consumo, quando mais presto for o processo de obsolescência, mais eficazmente far-se-ão segregações".

Lúcido, o escrito aponta a reverberação de tais conjunções na literatura desde as Luzes: relembra o escárnio de Montesquieu acerca da tolice dos costumes e da arbitrariedade das convenções vistos em Paris, o chincalho de Voltaire sobre a desafortunada busca dos parisienses pelo prazer, e a repulsa de Rousseau à corrupção disseminada nas grandes cidades. Nos tempos da diderotiana Encyclopédie, que postulava instituir o que fosse incondicionalmente o "homem" e a "razão", o autor observa a difusão de um "viés abstratizante" o qual, privilegiando conceitos universais, acaba por preterir o singular, e, assim, o indivíduo.

Nesse cenário, comparece, hiperbólica, a descrição do aparecimento de outra nova personagem, a "multidão", massa inquieta, que marca e abala, formada pela dissolução do sujeito e pela diluição das personalidades. Os olhos dirigidos à metrópole divisam conluios, conjuras e conspirações, presenciam a proliferação de jornais, folhetins, réclames e affiches, testemunham exposições nacionais e universais, acompanham a construção de lojas de departamentos, de galerias, de jardins e parques públicos, assimilando os novos comportamentos coletivos, mas também, por outro lado, advertem a melancolia e a nostalgia que denunciam resistência aos novos modos.

$\mathrm{Na}$ comovente elocução de Ricardo Marques sobre a metrópole também atuam romances - como os de Balzac, Stendhal, Dickens e Poe -, além da poética baudelaireana que desposa a multidão e flagra no proscênio parisiense "variadas personificações do moderno: o snob, $o$ apache, o flâneur, o dândy $e$ uma passante, que se apresentam nos caffés, boulevards, cabarets e galeries". Imerso na lírica que canta a Paris fin-de-siècle, o leitor sorve a nova sensibilidade da arte simbolista e é convocado a contemplar, mentalmente, a desvanescente luz da pintura impressionista a capturar, com o olhar de relance, a instantaneidade dos acontecimentos.

Se, por um lado, a abstração e a impessoalidade albergadas na metrópole provocam indiferença, desesperança, cansaço e ansiedade, por outro lado despertam modernas visões, como a de Mondrian, que toma a metrópole como o lugar no qual se desenvolve "o temperamento artístico matemático vindouro, de onde emergirá o novo estilo". Entretanto, convém sublinhar, ao contrário da historiografia "encomiástica" do movimento moderno - como a cunhada por Pevsner, Giedion, Zevi e Benevolo - que convencionou atribuir suas nascentes às circunstâncias da Revolução Industrial, Ricardo Marques, alinhando-se às interpretações críticas propostas por Kaufmann, Scully, Collins, e sobretudo Rykwert, reconhece nos embates e debates das Luzes parte dos valores e idéias retomados pelas vanguardas do século 20 . Com grande erudição, o autor adverte ser o século 18, e não o 19, aquele "que recupera a idéia de uma Natureza que abarca a natureza humana, tendo-se esta por ilimitadamente perfectível, a par do avanço da Ciência. Gênese e progresso, triunfo anunciado do esclarecimento sobre as sombras, são, como dos savants iluministas, temas dos construtivos". Todavia, acutíssimo, o autor ainda atenua a anacrônica leitura dos escritos de Kaufmann e que tomavam Lodoli como o prenunciador do moderno funcionalismo, bem como a pretensão de Tafuri de surpreender um viés 
vanguardista nas gravações e nos escritos de Piranesi: "não é, contudo, pelas premonições de alguns heróis do século XVIII, nem por um putativo vanguardismo das Luzes - procurado onde não poderia existir -, que se pode relacionar as postulações das vanguardas e das Luzes".

Em Metrópole: Abstração as vanguardas, além de positivas, são também ilustradas; anunciam a construção de um Novo Mundo no qual a arte, por inútil, desapareceria. Em seus manifestos, programam formas inusitadas de interação social, "racionalmente ordenadas no horizonte de vivências urbanizadas", e que, concebendo a superação de pretéritos arraigamentos, postulam a recuperação de ansiadas igualdade e pureza originárias e, assim, projetam a erradicação do fastio e da angústia os quais acometem o metropolitano.

Vivificando a kierkegaardiana angústia, Ricardo Marques revela, em uma alegoria, a historicidade dos vanguardismos. Defrontando-se com o fim, o leitor compreende que a angústia já estava patente na abertura do livro, na musiliana epígrafe do Homem sem qualidades, e, de alguma sorte, também o acompanhou na jornada pela metrópole. Eis outro dos fascínios da escrita de Ricardo Marques, que, no fim, convida para o retorno ao início.

\section{Andréa Buchidid Loewen}

Doutoranda em história e fundamentos da arquitetura e do urbanismo pela FAUUSP, é professora dos cursos de Arquitetura e Urbanismo da PUC-Campinas e da Universidade São Francisco.

e-mail: andrealoewen@ig.com.br; andrealoewen@uol.com.br 